\title{
CHEMICALLY CHITOSAN MODIFIED WITH METHYL METHACRYLATE AND ITS EFFECT ON MECHANICAL AND THERMAL PROPERTIES OF POLYPROPYLENE COMPOSITES
}

\author{
Faisal Amri Tanjung ${ }^{1,}$, Salmah Husseinsyah", \\ Kamarudin Hussin ${ }^{1}$, and Iqmal Tahir \\ ${ }^{1}$ School of Materials Engineering, Division of Polymer Engineering \\ Universiti Malaysia Perlis, 02600, Jejawi, Perlis, Malaysia \\ ${ }^{2}$ Department of Chemistry, Faculty of Mathematics and Natural Sciences, \\ Universitas Gadjah Mada, Sekip Utara, Yogyakarta Indonesia 55281
}

Received February 6, 2013; Accepted July 2, 2013

\begin{abstract}
Effects of methyl methacrylate on the properties of chitosan-filled polypropylene (PP) composites has been investigated. Mechanical and thermal properties of the composites were analyzed according to ASTM D 638-91, thermogravimetry analysis (TGA) and differential scanning calorimetry (DSC). The results showed that tensile strength of PP composites decreased upon the addition of chitosan, while Young's modulus improved. At a similar filler loading, the treated PP/chitosan composites were found to have higher tensile strength and Young's modulus as compared with the untreated composites. Thermal analysis results showed that thermal stability and crystallinity of the treated composites were higher than the untreated ones. Scanning electron microscopy (SEM) and Fourier transforms infrared (FTIR) studies revealed less detached filler from matrix on tensile surface of the treated composites as an evidence of enhanced filler-matrix interfacial adhesion due to formation of ester-bridge between the chitosan and the methyl methacrylate.
\end{abstract}

Keywords: polypropylene; chitosan; composites; methyl methacrylate; interfacial adhesion

\section{ABSTRAK}

Pengaruh metil metakrilat terhadap sifat-sifat komposit polipropilena (PP) terisi kitosan telah diteliti. Sifat mekanik dan sifat termal komposit dianalisis menggunakan ASTM D 638-91, analisis thermogravimetri and differential scanning calorimetry (DSC). Hasil-hasil yang diperoleh menunjukkan bahwa kekuatan tarik komposit PP menurun dengan penambahan kitosan, sedangkan modulus Young meningkat. Pada jumlah pengisi yang sama, komposit PP/kitosan dengan perlakuan ternyata memiliki kekuatan tarik dan modulus Young yang lebih tinggi dibandingkan dengan komposit tanpa perlakuan. Analisis termal menunjukkan bahwa kestabilan termal dan kristalinitas komposit dengan perlakuan lebih tinggi daripada komposit tanpa perlakuan. Kajian SEM dan FTIR menunjukkan pengurangan pengisi yang terlepas dari matriks pada permukaan patahan komposit dengan perlakuan sebagai sebuah bukti peningkatan ikatan antarmuka pengisi dan matriks yang disebabkan pembentukan jembatanester antara kitosan dan metil metakrilat.

Kata Kunci: polipropilena; kitosan; komposit; metil metakrilat; ikatan antarmuka

\section{INTRODUCTION}

Recently, the utilization of natural fibers as filler or reinforcement in thermoplastic composites is being more attractive. This trend is mainly encouraged by economic and environmental factors [1]. Since thermoplastic composites prepared using natural fibers are inexpensive and could minimize environmental pollution due to their characteristics bio-degradability, they could play a vital role in solving the environmental problems [23]. Among the advantages of using natural fibers in

* Corresponding author. Tel/Fax : +604-9798178

Email address : icalamri@gmail.com thermoplastic composites are low density, low abrasion to equipment, increase in modulus of elasticity (Young's modulus) and renewability [4]. However, some drawbacks are lower ultimate strength and elongation, increased water sorption, and difficulty in processing [5]. In general, when natural fillers or fibers are added to thermoplastics, properties such as elastic modulus, heat deflection temperature, moisture sorption and viscosity are increased whereas impact performance is reduced [6-8]. 
A large number of natural fibers are being used as filler to replace mineral fillers, such as wood fiber [9], sawdust [10], waste paper [11], jute [12], rice husk [13], sisal [14], and chitosan [15]. Chitosan is known as the second most abundant natural fiber after cellulose. It is extracted from crustaceous shells such as crabs, shrimp and prawns [16]. Currently, active researches have been conducted in the application of chitosan as biomaterials due to its biodegradability, biocompatibility and non toxicity, in spite of low cost, resource abundances, lightness and non abrasive nature [17].

The mechanical and physical properties of natural fiber filled thermoplastic composites are strongly influenced by the interaction on the interface between filler and matrix [18]. The interaction between the two components can be enhanced by physical and chemical modification of the filler or by using suitable coupling agents. Coupling agents are able to react with both components during the preparation of the composites, creating a chemical bridge at the filler-matrix interface [19-20].

Chitosan is a natural polysaccharide which tends to absorb water due to its hydrophilic characteristic, responsible to poor filler and matrix interfacial interaction. This becomes major drawback of using chitosan as filler in thermoplastic composites. This problem could be overcome by treating the filler. A number of attempts have been carried out in order to enhance the interaction between chitosan fiber and hydrophobic matrix. Salmah et al. [21] reported that the interfacial adhesion between chitosan and PP matrix was significantly enhanced by employing the 3-aminopropyltriethoxysilane (3-APE) as the chemical modifying agent in composite systems. In addition, in our previous work we have reported that better interfacial bonding and higher tensile strength of chitosan filled polypropylene (PP) composites were obtained by chemically treating the chitosan with sodium dodecyl sulfate [22].

In this study, methyl methacrylate was used as chemical modifying agent for treating the chitosan filler to enhance the interfacial interaction with PP matrix. Methyl methacrylate was chosen due to its reactive chemical moieties that may react with polar groups of chitosan i.e. hydroxyl and amine groups, to form a chemical bonding [23]. The formation of chemical bonding between chitosan and methyl methacrylate is expected to decrease the hydrophilic character of chitosan leading to enhance interfacial adhesion. Therefore, this study was aimed to investigate the effect of chemical treatment of chitosan by using methyl methacrylate on mechanical and thermal properties of polypropylene (PP) composites, while varying the chitosan loading.

\section{EXPERIMENTAL SECTION}

\section{Materials}

Polypropylene (PP) homopolymer used in this study was injection molding grade S11232 G112, from Polypropylenas Sdn Bhd (Malaysia) with MFI (melt flow index) value of $45 \mathrm{~g} / 10 \mathrm{~min}$ at $230{ }^{\circ} \mathrm{C}$. Chitosan was obtained from Hunza Nutriceuticals Sdn Bhd (Malaysia) with average size of $80 \mu \mathrm{m}$ and degree of deacetylation (DD) of $90 \%$. Ethanol (98\%.v/v) and methyl methacrylate were obtained from Aldrich.

\section{Instrumentation}

A Z-blade Mixer (MCN ELEC Co., Taiwan) was used for preparation of the composite. Tensile tests were carried out according to ASTM D 638-91 on an Instron 5582. Thermal analyses were investigated by using TGA Q500 Perkin Elmer Instrument and Perkin Elmer TA Instrument DSC Q 1000. A scanning electron microscope (SEM), model JSM 6260 LE JEOL, was used to study surface morphology of composites. FTIR spectroscopy analysis of untreated and treated chitosan was carried out in ATR mode by using PerkinElmer 1600 Series.

\section{Procedure}

\section{Preparation of treated chitosan}

Methyl methacrylate solution was prepared in ethanol at temperature of $40{ }^{\circ} \mathrm{C}$. The amount of methyl methacrylate used was 3 vol.\% of filler. The solution was then cooled down to room temperature. Afterward, chitosan was gradually added to the solution while slowly stirred. The mixture was mechanically stirred for $2 \mathrm{~h}$ in order to be homogenized and stayed overnight. The precipitate was filtered and then dried in the oven at $80{ }^{\circ} \mathrm{C}$ for $24 \mathrm{~h}$ to remove ethanol residue.

\section{Preparation of PP/chitosan composites}

$\mathrm{PP} /$ chitosan composites were prepared in a Zblade Mixer at temperature of $190{ }^{\circ} \mathrm{C}$ and rotor speed of $50 \mathrm{rpm}$. PP was first loaded to start the melt mixing. After $12 \mathrm{~min}$, the chitosan was added. Mixing was continued for another $3 \mathrm{~min}$. At the end of $15 \mathrm{~min}$, the $\mathrm{PP} /$ chitosan composites were taken out and sheeted through a laboratory mill at $2.0 \mathrm{~mm}$ nip setting. Samples of PP/chitosan composites were compression molded in an electrically heated hydraulic press. Hotpress procedures involved preheating at $190{ }^{\circ} \mathrm{C}$ for $9 \mathrm{~min}$ followed by compressing for $3 \mathrm{~min}$ at the same temperature and subsequent cooling under pressure for $3 \mathrm{~min}$. The same procedure was conducted for the preparation of treated PP/chitosan composites. The 
Table 1. Formulation of untreated and treated PP/chitosan composites

\begin{tabular}{lcc}
\hline \multicolumn{1}{c}{ Materials } & Untreated composites & Treated composites \\
\hline Polypropylene (PP) (php) & 100 & 100 \\
Chitosan (php) & $0,10,20,30,40$ & $10,20,30,40$ \\
Methyl methacrylate (vol.\%) & - & 3 \\
\hline php = part per-hundred polymer & &
\end{tabular}

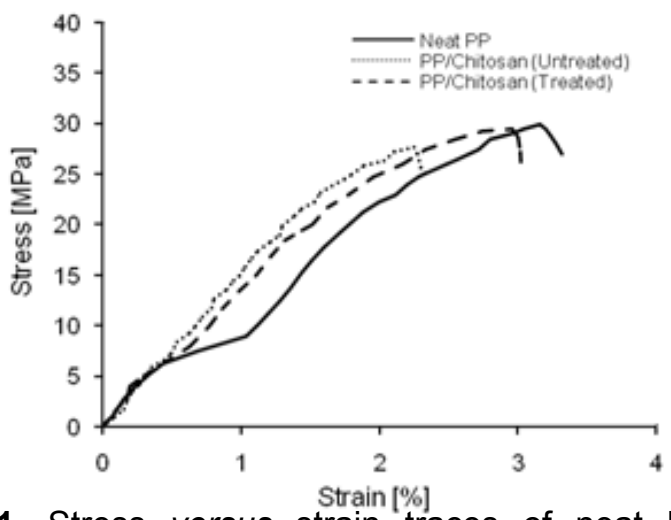

Fig 1. Stress versus strain traces of neat $P P$ and $\mathrm{PP} /$ chitosan composites with and without treatment

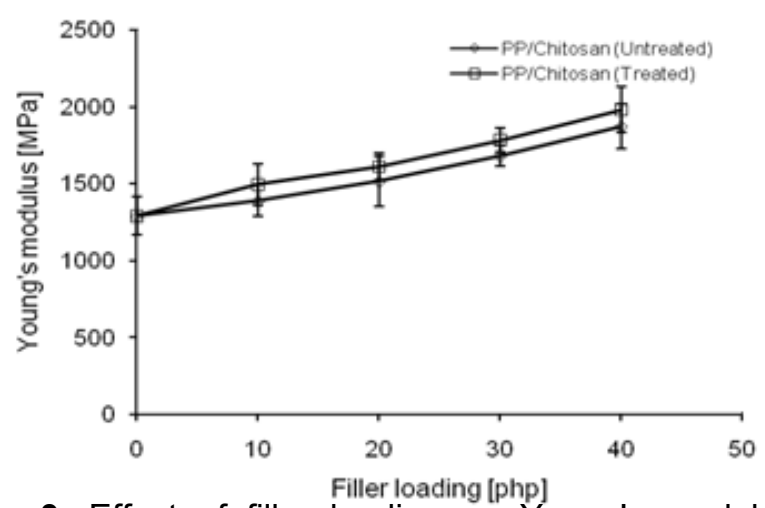

Fig 3. Effect of filler loading on Young's modulus of PP/chitosan composites

formulation of untreated and treated PP/chitosan composites is summarized in Table 1.

\section{Characterizations}

Tensile tests were carried out according to ASTM D 638-91. At least, five dumbbell specimens of each composition with thickness $1 \mathrm{~mm}$ were cut from the molded sheets with a Wallace die cutter. A cross head speed of $20 \mathrm{~mm} / \mathrm{min}$ was used and the test was performed at $25 \pm 3{ }^{\circ} \mathrm{C}$.

Thermogravimetric (TGA) and derivative thermogravimetric (DTG) analyses were investigated to study the thermal stability of the composites. Samples were scanned on TGA, from 30 to $600{ }^{\circ} \mathrm{C}$ at a heating rate of $20^{\circ} \mathrm{C} / \mathrm{min}$ using a nitrogen flow of $50 \mathrm{~mL} / \mathrm{min}$. On DSC analysis, samples were scanned from 25 to $250{ }^{\circ} \mathrm{C}$ at a heating rate of $20{ }^{\circ} \mathrm{C} / \mathrm{min}$ using nitrogen flow of $50 \mathrm{~mL} / \mathrm{min}$. The melting and enthalpy of PP/chitosan

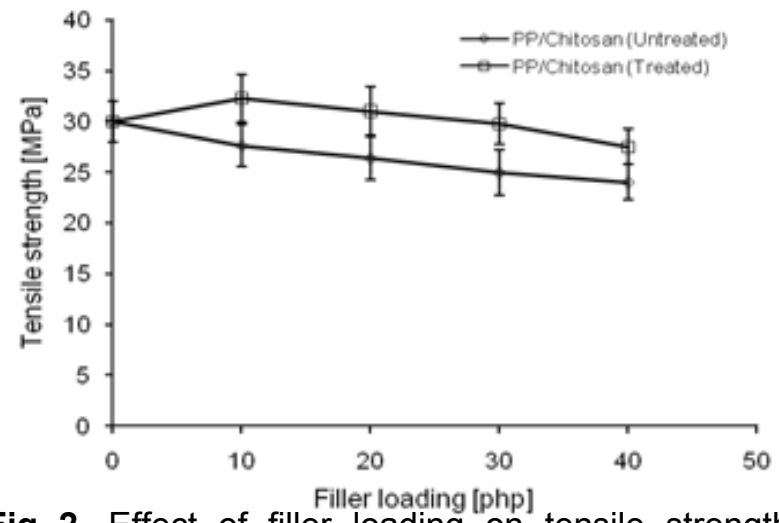

Fig 2. Effect of filler loading on tensile strength of $\mathrm{PP} /$ chitosan composites

composites were automatically calculated by the instrument software. The crystallinity of composites $\left(X_{c}\right)$ was determined using Equation 1:

$X_{c}=\Delta H_{f} \times 100 / \Delta H_{f}^{o}$

where $\Delta H_{f}$ is the heat of fusion of the PP and composites, $\Delta H_{f}^{o}$ is the thermodynamic heat of fusion of fully crystalline PP (209 J/g) [24]. A mean value of three replicates of each specimen was recorded.

Study on the morphology of the tensile fracture surface of the PP/chitosan composites was carried out by using a scanning electron microscope (SEM). The fracture ends of specimens were mounted on aluminium stubs and sputter coated with a thin layer of palladium to avoid electrostatic charging during examination.

Fourier transforms infra red (FTIR) spectroscopy analysis of untreated and treated chitosan was carried out. Samples were scanned from 650 to $4000 \mathrm{~cm}^{-1}$ with resolution of $4 \mathrm{~cm}^{-1}$.

\section{RESULT AND DISCUSSION}

\section{Tensile Properties of PP/Chitosan Composites}

Tensile test has been conducted to determine the strength of PP/chitosan composites when the force is given in tension. Stress versus strain traces recorded tensile testing for neat PP, untreated and treated PP composites containing 20 php chitosan filler are presented in Fig. 1. All traces exhibited a similar character; however, in some extent both untreated and treated PP composites showed lower strength and 

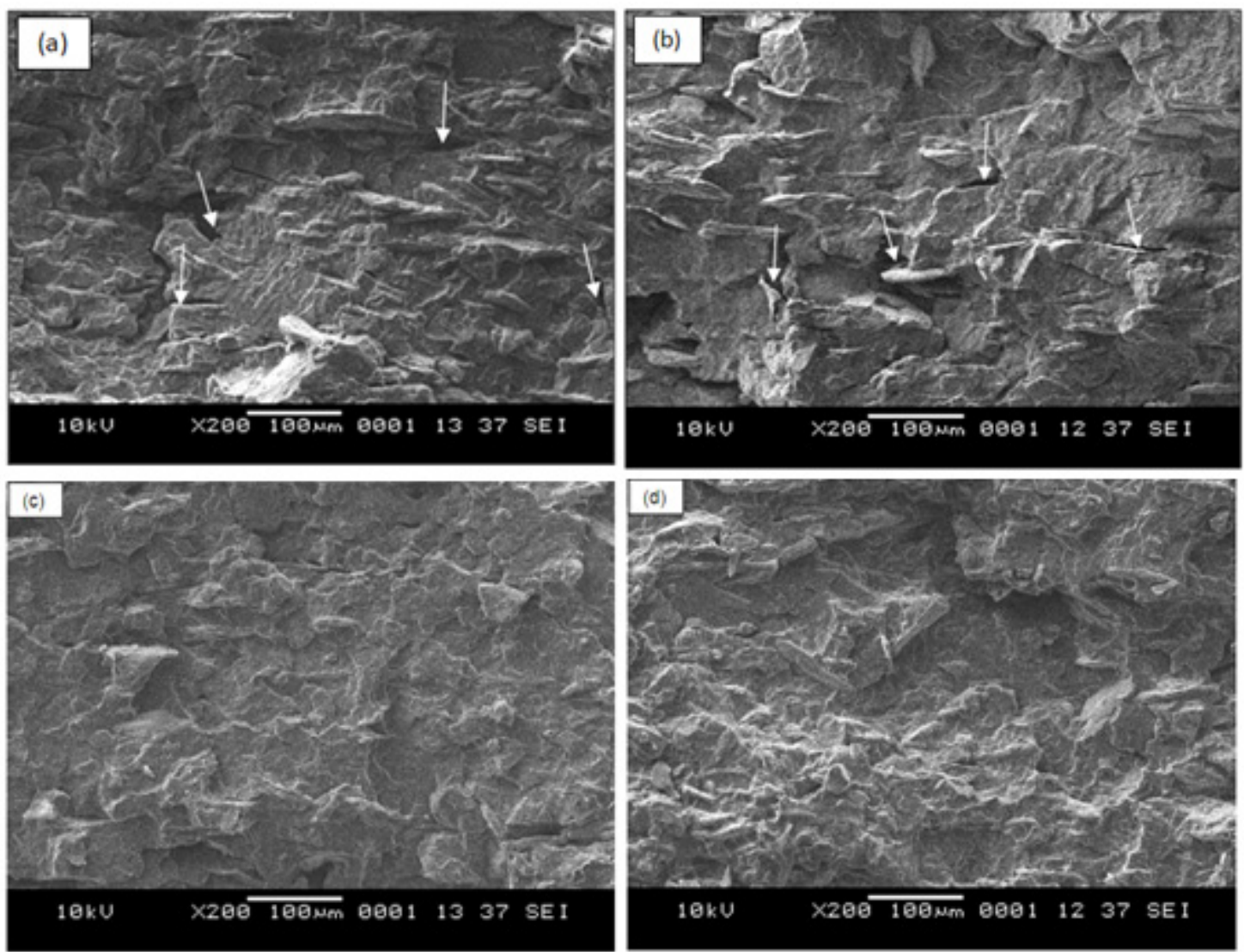

Fig 4. SEM micrograph of tensile surface; (a) untreated PP/chitosan composite (20 php); (b) untreated PP/chitosan composite (40 php); (c) treated PP/chitosan composite (20 php); (d) treated PP/chitosan composite (40 php); all magnifications are 200X. Arrows indicate traces of pulled out filler

ultimate strain than neat PP. The presence of chitosan as filler significantly influenced the strength of PP composites. Chemical treatment did not apparently change the stress versus strain trace character of the treated PP composites, but influenced the measured strength at failure. The use of methyl methacrylate increased both strength and ultimate strain of treated PP composites when compared to untreated ones.

Tensile strength of PP/chitosan composites as a function of filler loading is depicted in Fig. 2. Tensile strength of PP/chitosan composites decreased with the increasing of filler loading, which considerably due to the lack interfacial interaction between chitosan and PP matrix. Chitosan is natural polysaccharide with hydrophilic character, while PP is hydrophobic polymer. The different polarities diminish filler-matrix interfacial adhesion [25]. Hence, as the chitosan loading increased thereby increasing the interfacial area, the worsening interfacial interaction between filler and matrix has caused decreasing tensile strength. However, as the presence of methyl methacrylate on the chitosan surface, the tensile strength of treated PP composites was higher compared to untreated ones. It is worth noting that the hydrophilic character of chitosan was decreased due to the formation of ester-linkage between hydroxyl group of chitosan and ester group of methyl methacrylate through trans-esterification reaction, leading to enhanced interfacial adhesion with PP matrix.

Fig. 3 shows the Young's modulus of PP/chitosan composites at different filler loading. Increasing filler loading significantly improved the Young's modulus of PP/chitosan composites. The incorporation of chitosan into PP matrix decreased the deformability of PP composites as a result of constricted molecular motion of PP chain, subsequently improved the rigidity. As the filler loading increased, the PP/chitosan composites became more rigid and the Young's modulus increased. This result confirmed that Young's modulus was less sensitive to changes in interfacial interactions than properties measured at larger deformations. Otherwise, Young's modulus of treated PP/chitosan composites was significantly higher than untreated composites. This was due to the better dispersion of treated chitosan in PP composites inducing stiffening effect. 


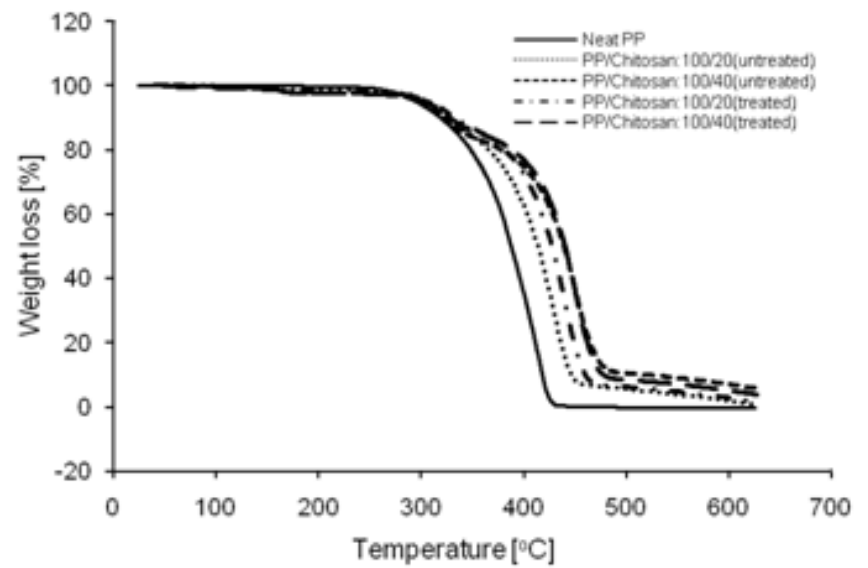

Fig 5. TGA curve of untreated and treated PP/chitosan composites

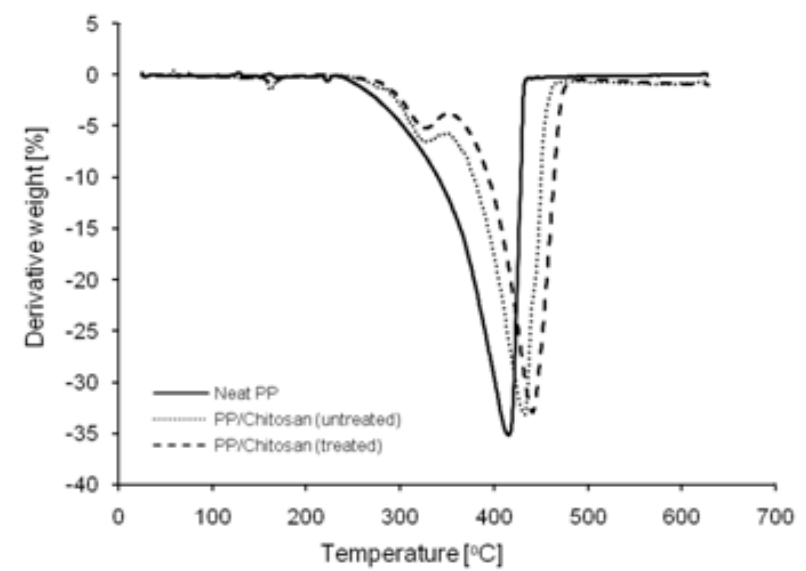

Fig 6. DTG curve of untreated and treated PP/chitosan composites

Table 2. Percentage of weight loss of neat PP and PP/chitosan composites at different temperature

\begin{tabular}{cccccc}
\hline \multirow{2}{*}{$\begin{array}{c}\text { Temperature } \\
\left({ }^{\circ} \mathrm{C}\right)\end{array}$} & \begin{tabular}{c} 
Weight loss of neat \\
\cline { 2 - 5 }
\end{tabular} & \multicolumn{2}{c}{$\begin{array}{c}\text { Weight loss of PP/chitosan } \\
\text { Composites (untreated) }\end{array}$} & \multicolumn{2}{c}{$\begin{array}{c}\text { Weight loss of PP/chitosan } \\
\text { Composites (treated) }\end{array}$} \\
\hline $100-150$ & 0.002 & 0.039 & $100 / 40(\mathrm{php})$ & $100 / 20(\mathrm{php})$ & $100 / 40(\mathrm{php})$ \\
$150-200$ & 0.016 & 0.271 & 0.277 & 0.560 & 0.534 \\
$200-250$ & 0.150 & 1.017 & 1.894 & 0.653 & 0.569 \\
$250-300$ & 0.476 & 0.157 & 0.212 & 1.803 & 1.075 \\
$300-350$ & 4.993 & 0.495 & 1.262 & 0.238 & 0.193 \\
$350-400$ & 14.813 & 4.540 & 5.080 & 4.176 & 2.016 \\
$400-450$ & 43.150 & 13.539 & 13.105 & 12.123 & 4.388 \\
$450-500$ & 36.400 & 30.499 & 36.512 & 39.742 & 11.987 \\
$500-550$ & 0 & 1.494 & 32.855 & 33.060 & 35.825 \\
$550-600$ & 0 & 1.886 & 1.428 & 1.429 & 31.904 \\
$600-630$ & 0 & 97.090 & 1.692 & 1.043 & 1.403 \\
Total & 100 & & 94.872 & 95.226 & 1.922 \\
\hline
\end{tabular}

php $=$ part per-hundred polymer

\section{SEM Study of PP/Chitosan Composites}

Fig. 4 shows SEM micrographs of tensile fractured surface of PP/chitosan composites. The micrographs of untreated PP/chitosan composites (Fig. 4(a) and 4(b)) show the appearance of voids indicating detached filler from the matrix. This is mainly due to poor wetting of the filler by the matrix. The fracture occurred at the interface between chitosan and PP matrix. The different polarities between filler and matrix lead to lack interaction on the interface especially at higher filler loading. However, the less voids are observed on the tensile surface of treated PP/chitosan composites (Fig. 4(c) and 4(d)). A good wetting of the filler by the matrix is related to the presence of methyl methacrylate, which hydrophobically modifies the chitosan, leading to enhanced interfacial adhesion with PP matrix.

\section{Thermal Properties of PP/Chitosan Composites}

Fig. 5 and 6 demonstrate TGA and DTG curve of neat $\mathrm{PP}$, untreated and treated PP/chitosan composites. The increase of temperature has dramatically increased the weight loss of neat PP, untreated and treated composites, and the results are summarized in Table 2. The thermal degradation of PP occurred in one-stage from 300 to $415{ }^{\circ} \mathrm{C}$ resulting gaseous products. It pointed out that PP is composed from carbon-carbon bonds chain and the degradation/depolymerization taking place at the weak sites of PP chain. Meanwhile, the thermal degradation of PP/chitosan composites occurred in two-stage; from 50 to $300^{\circ} \mathrm{C}$ corresponded to the release of typical strong hydrogen-bonded water and the breakage of chemical bonds; and from 300 to $450{ }^{\circ} \mathrm{C}$ might be associated to decomposition and depolymerization of chitosan filler. There was another degradation stage occurring from 470 to $600{ }^{\circ} \mathrm{C}$ that attributable to the decomposition of char residue formed from the second stage. At a similar loading, the thermal stability of treated PP/chitosan composites was better than untreated ones, remarkably accompanied by the formation of ester-bond between hydroxyl group of chitosan filler and ester group of methyl methacrylate that suppressing the weight loss. Overall, the 
observation clearly exhibits that neither the presence of chitosan filler at higher loading nor the presence of methyl methacrylate did alter the thermal degradation mechanism of PP/chitosan composites.

Fig. 7 shows DSC curves of neat PP, untreated and treated PP/chitosan composites at $20 \mathrm{php}$ filler loading. Table 3 summarizes the melting temperature $\left(T_{m}\right)$, fusion enthalpy $\left(\Delta H_{f}\right)$ and degree of crystallinity $\left(X_{c}\right)$ of neat PP, untreated and treated PP/chitosan composites. As can be seen, the addition of chitosan filler did not significantly change the $T_{m}$ of PP composites, but, decreased the degree of crystallinity $\left(X_{c}\right)$. This indicates that the presence of chitosan in PP composites apparently become barrier on nuclei-growth of PP chain and delayed the crystallization process. Furthermore, the addition of natural filler into PP matrix obstructed the mobilization of the PP macromolecular chain and prevented the macromolecular segment from obtaining ordered alignment of the crystal lattice [26]. On the other hand, the treated PP/chitosan composites were obtained to have higher crystallinity than untreated $\mathrm{PP} /$ chitosan composites, remarkably due to enhanced interfacial bonding between chitosan and PP matrix. It is worth noting that methyl methacrylate favors the enhanced chitosan-PP matrix interfacial interaction, leading to increased crystallinity of PP composites. The treated chitosan surfaces were indicated as nucleigrowth sites for promoting the crystallization process in PP composites. However, the $\mathrm{T}_{\mathrm{m}}$ did not significantly change when compared with untreated composites, possibly due to the non- uniformity of crystal shape and lattice resulting from different types of nucleation sites [27].

\section{FTIR Study of Untreated and Treated Chitosan}

Fig. 8 presents the FTIR spectra of untreated and treated chitosan. As can be seen, the infrared (IR) spectrum of untreated chitosan, the main characteristic

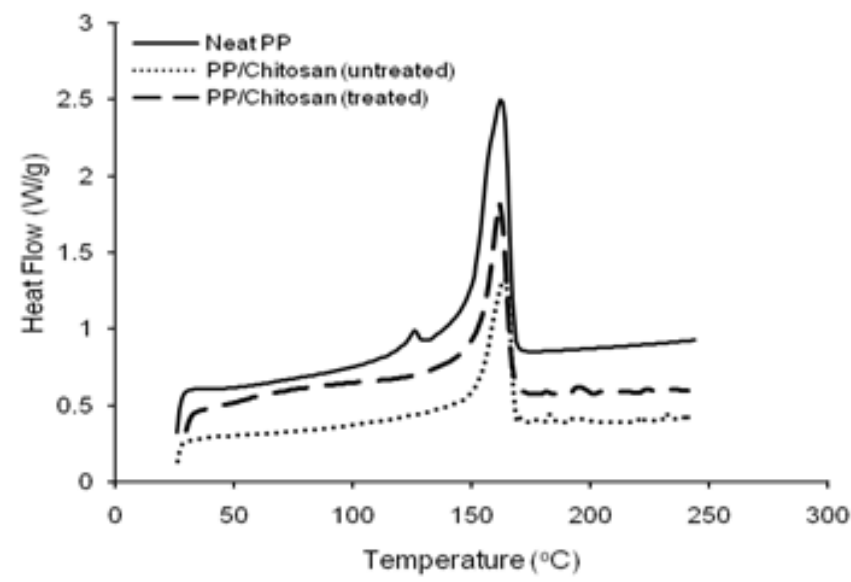

Fig 7. DSC curve of untreated and treated PP/chitosan composites containing filler loading of $20 \mathrm{php}$

Table 3. Summary of $\mathrm{T}_{\mathrm{m}}$ and $X_{c}$ of neat PP and $\mathrm{PP} /$ chitosan composites

\begin{tabular}{lcc}
\hline \multicolumn{1}{c}{ Composites } & $\mathrm{T}_{\mathrm{m}}\left({ }^{\circ} \mathrm{C}\right)$ & $X_{\mathrm{c}}(\%)$ \\
\hline Neat PP & $162(0.2)$ & $38.74(0.3)$ \\
PP/chitosan: 100/20 (untreated) & $163(0.3)$ & $24.13(0.2)$ \\
PP/chitosan: 100/40 (untreated) & $163(0.1)$ & $19.81(1.0)$ \\
PP/chitosan: 100/20 (treated) & $164(0.5)$ & $28.59(0.5)$ \\
PP/chitosan: 100/40 (treated) & $164(0.3)$ & $22.76(0.4)$
\end{tabular}

php = part per-hundred polymer; $\mathrm{T}_{\mathrm{m}}=$ melting temperature; $X_{c}=$ crystallinity degree

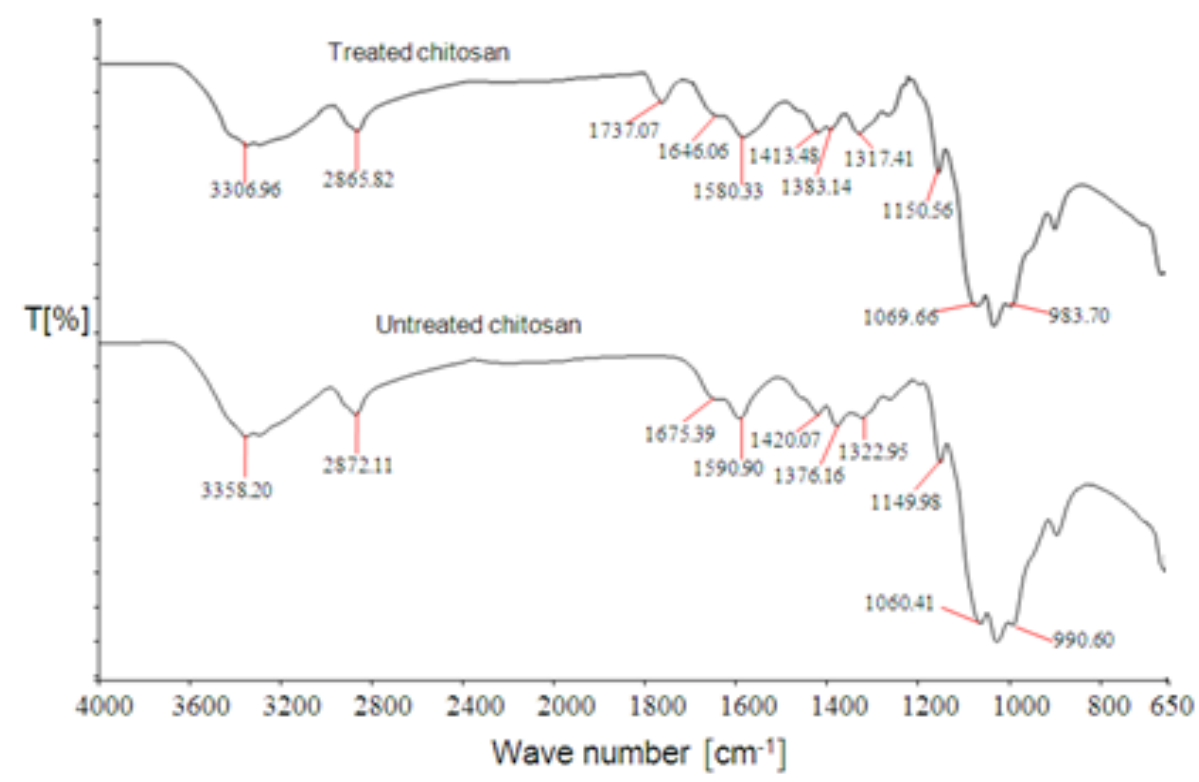

Fig 8. Infrared (IR) spectra of untreated and treated chitosan 
peaks of chitosan, are at $3358 \mathrm{~cm}^{-1}(\mathrm{O}-\mathrm{H}$ stretch), $2872 \mathrm{~cm}^{-1}$ (C-H stretch), $1675 \mathrm{~cm}^{-1}(\mathrm{~N}-\mathrm{H}$ bend $)$ and $1590 \mathrm{~cm}^{-1}$ (C=O stretch). The IR spectrum of treated chitosan exhibits a significant absorption on the band of -OH group from 3358 to $3306 \mathrm{~cm}^{-1}$, indicating the reduction in hydrophilic character of chitosan. This is attributed to the presence of ester-bridge as a result of trans-esterification reaction between ester group of methyl methacrylate and hydroxyl group of chitosan as identified by the presence of the absorption band at $1737 \mathrm{~cm}^{-1}$. The formation of this bonding is also supported by the reduction of the bands at $1675 \mathrm{~cm}^{-1}$ to $1646 \mathrm{~cm}^{-1}$ and $1590 \mathrm{~cm}^{-1}$ to $1580 \mathrm{~cm}^{-1}$, indicating $\mathrm{N}-\mathrm{H}$ bending vibration and amide I $(\mathrm{C}=\mathrm{O})$ stretching vibration of chitosan chain.

\section{CONCLUSION}

Chitosan, a kind of natural filler was incorporated into PP matrix to produce composite materials. Methyl methacrylate was employed as chemical treating agent to reduce the polar character of the chitosan filler. Tensile test results showed that the incorporation of chitosan filler into PP matrix reduced the tensile strength, but increased the Young's modulus. The treated PP/chitosan composites were observed to have higher tensile strength and Young's modulus than untreated PP/chitosan composites. The thermal analysis results showed that the treated PP/chitosan composites had higher thermal stability and crystallinity than untreated ones. Additionally, it was found that chemical treatment did not alter the thermal degradation mechanism of treated PP/chitosan composites when compared with untreated ones. FTIR spectra and SEM micrographs revealed that methyl methacrylate was successfully bonded onto the chitosan surface, leading to enhanced interfacial adhesion with PP matrix.

\section{ACKNOWLEDGEMENT}

Research fund under Fundamental Research Grant Scheme (FRGS) by Ministry of Science, Technology and Innovation (MOSTI) of Malaysia is greatly acknowledged.

\section{REFERENCES}

1. Toris, G., Denes, F., and Young, R.A., 2002, Polym. Compos., 23, 5, 806-813.

2. Choi, N-W., Mori, I., and Ohama, Y., 2006, Waste Manage., 26, 2, 189-194.

3. Rahman, M.R., Huque, M.M., Islam, M.N., and Hasan, M., 2009, Composites Part A, 40, 4, 511517.
4. Dányádi, L., Janecska, T., Szabó, Z., Nagy, G., Móczó, J., and Pukánszky, B., 2007, Compos. Sci. Technol., 67, 13, 2838-2846.

5. Nuñez, A.J., Sturm, C.P., Kenny, M.J., Aranguren, M.I., Marcovich, N.E., and Roberedo, M.M., 2003, J. Appl. Polym. Sci., 88, 6, 1420-1428.

6. Avella, M., Casale, L., Dell'erba, R., Focher, B., Martuscelli, E., and Marzetti, A., 1998, J. Appl. Polym. Sci., 68, 7, 1077-1089.

7. Abdelmouleh, M., Boufi, S., Belgacem, M.N., and Dufresne, A., 2007, Compos. Sci. Technol., 67, 78, 1627-1639.

8. Ashori, A., and Nourbakhsh, A., 2010, Composites Part B, 41, 7, 578-581.

9. Dányádi, L., Móczó, J., and Pukánszky, B., 2010, Composites Part A, 41, 199-206.

10. Fernanda, M.B., Coutinha, H.C., Joao, C.S.M., and Daniele, P.M., 2000, Polym. Test., 19, 625-629.

11. Faisal, A., and Salmah, H., 2012, J. Thermoplast. Compos. Mater., 25, 193-207.

12. Chand, N., and Dwivedi, U.K., 2006, Wear, 261, 10, 1057-1063.

13. Panthapulakkal, S., and Sain, M., 2007 , Composites Part A, 38, 6, 1445-1454.

14. $\mathrm{Li}, \mathrm{H} ., \mathrm{Hi}, \mathrm{C}$. , and $\mathrm{Yu}, \mathrm{Y} ., 2008$, Composites Part $A$, 39, 4, 570-578.

15. Kabiri, K., Mirzadeh, H., and Zohuriaan-Mehr, M.J., 2007, Iran. Polym. J., 16, 3, 147-151.

16. Di Martino, A., Sittinger, M., and Risbud, M.V., 2005, Biomaterials, 26, 30, 5983-5990.

17. Prashanth, H.K.V., and Tharanathan, R.N., 2007, Trends Food Sci. Technol., 18, 3, 117-131.

18. Balasuriya, P.W., Ye, L., Mai, Y-W, and Wu, J., 2002, J. Appl. Polym. Sci., 83, 12, 2505-2521.

19. Bengtsson, M., and Oksman, K., 2006, Composites Part A, 37, 5, 752-765.

20. Gironès, J., Méndez, J.A., Boufi, S., Vilaseca, F., and Mutjé, P., 2007, J. Appl. Polym. Sci., 103, 6, 3706-3717.

21. Salmah, H., Faisal, A., and Kamarudin, H., 2011, Int. J. Polym. Mater., 60, 7, 429-440.

22. Faisal, A., Salmah, H., and Kamarudin, H., 2013, J. Thermoplast. Compos. Mater., (in press) Doi: 10.1177/0892705711430430.

23. Supri, A.G., Tan, S.J, Ismail, H., and Teh, P.L., 2011, Polym. Plast. Technol. Eng., 50, 898-906.

24. Joseph, P.V., Joseph, K., Thomas, S., Pillai, C.K.S., Prasad, V.S., Groenickx, G., and Sarkissova, M., 2003, Composites Part A, 34, 3, 253-266.

25. Mir, S., Yasin, T., Halley, P.J., Siddiqi, H.M., and Nicholson, T., 2011, Carbohydr. Polym., 83, 2, 414-421. 
26. Sui, G., Fuqua, M.A., Ulven, C.A., and Zhong, W.H., $\quad$ 27. Wang, C., and Liu, C-R., 1999, Polymer, 40, 2 , 2009, Bioresour. Technol., 100, 3, 1246-1251. 289-298. 